\title{
The Vocational Teachers Challenges in Developing Their Professional Competence
}

\author{
Indra Yoga Prawiro \\ Wiralodra University \\ yogaprawiro@gmail.com
}

\begin{abstract}
This study focuses on investigating the challenges of vocational teachers in developing their professional competence. This study describes kinds of challenges that the teachers have faced to develop their professional competence. This study used qualitative as the approach and case study as its research design. The subjects of this study were five ESP teachers who have been teaching in Vocational Schools in Indramayu at least for about 5 years. To collect the data, the writer used open-ended questionnaire, interview and test. The data analysis was conducted in several ways. The data from questionnaire were analyzed in several steps, there are coding, analyzing and interpreting. Then, the data from interview were transcribed and the data from the test were analyzed qualitatively. The result of the study shows that there are some challenges faced by the teachers in developing their professional competence. Those challenges are the availability of seminars and workshops in their city, the less support from the institution and the lack of facilities and infrastructure.
\end{abstract}

\section{ARTICLE HISTORY}

Received 23 October 2019

Accepted 25 November 2019

\section{KEYWORDS}

Professional competence development; challenges; and vocational teachers

\section{Introduction}

In Indonesia, since decades ago, the education movements have been introduced to develop the quality of the people. The Indonesian government works so hard to create a marvelous design of education that can form an excellent generation with good knowledge, massive skill and likeable behavior. In order to reach those purposes, the government should focus on the development of secondary school because secondary education is a bridge for young people from the school area to the work area. According to UNESCO's Director General, expanding secondary schooling is a minimum entitlement for equipping youth with the knowledge and skills they need to secure decent livelihoods in today's globalized world. Without opportunities for secondary education, children have little chance to improve their livelihoods and give contribution to the progress of the world. 
However, teaching in secondary schools especially in vocational schoolshave been criticized as ineffective in preparing competent individuals (Bedi and Sharma, 2006: 2 ;Davidson, 2006: 3). Secondary school students are claimed to finish school as unprepared individuals who fail to demonstrate competencies in work and life (Benson, 2005: 3) and hence become a burden for their societies (Shahzad, 2007: 2). Teaching and learning in secondary schools are also claimed to produce only temporary knowledge and skills that are used only in answering examinations (Malekela, 2000: 4; Wedgwood, 2006: 9). Therefore, we need also to prepare appropriate teachers to teach our students a secondary level. The teachers need a deep knowledge of how to teach their specific subject (Krauss et al., 2008: 3; Shulman, 1987: 12), for effective practice in diverse, multicultural, inclusive learning environments.

In order to minimize those challenges, our government has also made the standardized competencies that should be mastered by the teachers; those are pedagogic, personal, social and professional competence (Act 14/2005 article 10). The first, pedagogical competence is the ability of teachers to understand the dynamics of the learning process. The second, professional competence can be explained as the mastery of learning materials, mastery of curriculum content and substance of scientific subjects philosophically (Jamal, 2009:157). The third, personal competence is the ability of teachers to demonstrate attitudes and personality that can be imitated and obeyed by their students. The last, social competence is the ability of teachers to interact and communicate. Therefore, in accordance with the explanation above, this study attempts to know the challenges of vocational teachers in developing their professional competence.

\section{Literature Review}

\section{Teacher Competencies}

The existence of qualified teacher in improving education is really important. Several studies have shown that the quality of the individual teacher is one of the most significant variables influencing how much progress students make in schools, Hanushek\&Rivkin (2006: 1053). Teacher determines how the success of the students. In his/her hands the students are guided to be what really they are. How good the curriculum in education system, the final execution is on teacher's mind and performance. That is why when new curriculum is launched, teacher becomes one who determines its success.

Besides academic qualification, teacher should have competencies as well. The regulation from national education ministry also regulate about the competencies that should be owned by a teacher. A competence is described as 'a complex combination of knowledge, skills, understanding, values, attitudes and desire which lead to 
effective, embodied human action in the world, in a particular domain' (Crick, 2008:313). Competence is therefore distinguished from skill, which is defined as the ability to perform complex acts with ease, precision and adaptability.

As it is stated in Permendiknas No.16 year 2007 that the competencies of teacher are: 1. Pedagogical competence, 2. Personal competence, 3. Professional competence and 4 social competence. Therefore, in Indonesia a teacher can be called as qualified teacher when those four main competencies are mastered.

\section{Professional Competence}

Teachers can be popular just because they are friendly and helpful, but to be truly professional and effective they need other qualities. One of requirements that should be achieved by the teachers is knowledge. The statement is in line with Schon (1983: 25) who explained professional Competence as factual knowledge and the ability to solve the challenges with clear-cut solution: it is defined by the ability to manage ambiguous challenges, tolerate uncertainty, and make decisions with limited information. Whereas, Jamal (2009: 157) stated that professional competence is the mastery of learning materials is broad and deep, covering mastery of curriculum content and substance of scientific subjects philosophically. Therefore, based on those explanations, it can be concluded that professional competence is the ability to mastery the knowledge and information in order to teach the students in the class, face the challenges in the process of learning and also learn the new things in teaching.

However, there are some qualities that teachers should be prioritized to support teachers' professional development. Richards \& Farrell (2005: 9) described a number of areas of professional development may be identified:

1) The ability of teachers to mastery subject knowledge of lesson. Some knowledge that should be increased includes: increasing knowledge of the disciplinary basis of TESOL-that is, English grammar, discourse analysis, phonology, testing second language acquisition research, methodology, curriculum development, and the other areas that define the professional knowledge base of language teaching.

2) The knowledge of teachers to master the new areas of teaching, adding to one's repertoire of teaching specializations, improving ability to teach different skill areas to learners of different ages and backgrounds.

3) The knowledge of oneself as a teacher. It includes the knowledge of teachers about his/her strengths and weaknesses.

4) The ability of teachers in understanding their learners. It includes deepening understanding of learners, learning styles, learners' problems and difficulties, ways of making content more accessible to learners.

5) The ability of teachers in understanding the curriculum and materials. It includes deepening understanding of curriculum and curriculum alternatives, use and development of instructional materials. 
6) The understanding of teachers in developing their career. It includes acquisition of the knowledge and expertise necessary for personal advancement and promotion, including supervisory and mentoring skills,

In this case, Richards and Farrell explained several area of development. From the statements above it can be seen that the focus of development process in professional competence is on developing knowledge and increasing the understanding. The teachers, as the primary informant in the class, have to continuously upgrade their knowledge because the curriculum is always changing and the goal of education is always extended.

\section{The Process for Professional Competence Development}

Professional development should be designed around research-documented practices that enable educators to develop the skills necessary to implement what they are learning. Thus, the process of professional development should also be based on sound educational practice such as contextual teaching (Joyce \& Showers, 2002: 2). The contextual teaching presents information in familiar contexts and in contexts in which the information is useful, Marzano, et al. (2001: 51). It is effective because it takes advantage of the fact that learning occurs best when learners process new information or knowledge in such a way that it makes sense to them in their own frames of reference. Therefore, it can be concluded that the process of professional development should be based on the understanding of the teachers that the development process is used to support their carrier in teaching. When the teachers start to develop their competence, they will learn what the weaknesses of them are. This condition will make the teachers realize to seek kind of method that is appropriate for them to solve the challenges.

\section{Teaching Vocational Students}

As an important and distinctive branch of English Language Teaching (ELT), English for Specific Purposes focuses on practical aspects derived from needs analysis, genre analysis and effective communication. The extraordinary growth of this discipline is also a result of the developments in economy, industry, commerce and communications. The scientific discoveries and technical innovations of the "information age" have triggered bilingual and multilingual communication to become a significant issue in our modern society.

Consequently, there has been an increased demand for language courses and new approaches to language teaching/learning foreign languages. Furthermore, Hutchinson and Waters (1987: 18) explain that ESP is not a matter of teaching specialized varieties of English. ESP is not just a matter of science words and grammar for Scientists, Hotel words and grammar for Hotel staff and so on. ESP is not different in kind from any 
other form of language teaching in that it should be based in the first instance on principles of effective and efficient learning.

Johns \& Price-Machado (2001: 44) explained English for Specific Purposes (ESP) as a movement based on the proposition that language teaching should be tailored to the specific learning and language use needs of identified groups of students. Whereas, Robinson (1991: 3) described ESP as normally 'goal-directed' and it's developed based on a need analysis which aim to specify what exactly it is that the students have to do through the medium of English, and a number of characteristics which explain that ESP courses are generally constrained by a limited time period in which their objectives have to achieved and are taught to adults in homogenous classes in terms of the work or specialist studies that the students are involved in.

\section{Methodology}

In this study, the writer used descriptive qualitative research that was case study, as the research design to explore and describes the issue based on the individual perspectives. This study is describing and explaining a phenomenon among the English teachers in vocational schools who graduated from English department of Wiralodra University. This study is individually describing the challenges of Vocational teachers in developing their professional competence. The individual differences become one of the targets in describing that phenomenon.

\section{Findings and Discussions}

According to the interview session and questionnaire there are three major challenges that the $1^{\text {st }}$ teacher found in developing her professional competence. The first is her lack of understanding towards the 2013 curriculum. In the interview session, she stated that she has taught by using 2013 curriculum for one semester. In her opinion, it is difficult for her to understand the scoring system of 2013 curriculum. Besides, it takes times to fill the score; she also thinks that it is so complicated. Inthe interview session, she stated that

The scoring system also in 2013 curriculum is really hard...for me because I...I cannot understand the scoring system of 2013 curriculum.

Although she has followed the workshop of 2013 curriculum, she thinks that it is not effective to make the teacher understand the curriculum. She understands that the changing curriculum is used to improve the quality of education in Indonesia but the government needs an extra time to prepare it before its implementation in the school. In the interview session she stated that:

Yeah it's always being controversial for every changing in this country right? So

I think...the government should more wise...more wise to consider or to make 
...to make the new rules, especially for education, the government don't...don't only think the product of the students but also think about how teacher work.

She suggested the government make the priority in improving the quality of education in Indonesia, because the one who takes bigger responsibility is the teacher. Then another problem she found in the field when she tries to develop her knowledge and information is the limited access of internet because most of the material, video and etc. that the $1^{\text {st }}$ teacher needed are taken from the internet. therefore, minimum access of internet becomes the challenges in developing her knowledge.

Then another problem that she found is limited access to join seminars or workshops. As a teacher who teaches in small city like Indramayu, the $1^{\text {st }}$ teacher cannot easily find an English seminar that can increase her knowledge in teaching English. She stated that

Yeah...major thing is...I think it was the information that I got is...is not...good ...I mean there are rare information about the seminar itself even if I got, sometimes...the seminar...was held in the other...in out of town so I should...I mean I should have more money right.

So even though, the $1^{\text {st }}$ teacher understands the importance of seminar in developing her professional competence, she cannot deny her personal needs and financial capability in joining seminars.

Furthermore, The $2^{\text {nd }}$ teacher explains several challenges that she found during the professional competence development. The first is related to the financial challenges. As apart-time teacher, it is very hard for her to join seminars and pay it by herself

Yes I find many challenges in developing my professional competence. One is because I am still apart-time teacher and have limited financial. Therefore, I hardly ever attended the seminars outside the city.

Actually workshops or seminars can be used as one of the efforts that should be followed by the teachers to improve their knowledge. The statement is suppoerted by Richards and Farrell (2005) who stated that "a workshop is intended to enhance teachers' practical skills and help resolve challenges, rather than simply improve theoretical understanding". Teachers attending a workshop should therefore come away with ideas, strategies, techniques, and materials that can be used in their classrooms. In fact, the $2^{\text {nd }}$ teacher cannot join seminars or workshops because there is no regular workshop provided by government in her city. Even if there is any seminar, it is really burden her when she has to pay the seminarfee by herself. 
Then, the second problem is the lack of facilities and infrastructure in her Vocational School. As a new State Vocational School in Indramayu, there are many challenges related to the facilities and infrastructure. For example, there is no Wi-Fi that can be used to seek the information. Then, concerning minimum number of sound system and other utilities that can support teaching and learning in the class, $2^{\text {nd }}$ teacher stated that

Beside that, facilities and infrastructure in my school are not inadequate to help me in presenting the material. The changing curriculum is also quite difficult for me to understand.

The changing curriculum always happens in several countries including in Indonesia. It is proposed by the government in order to improve the quality of students in Indonesia. However, the changing always brings its own challenges. One of them is the readiness of teacher towards the implementation of that curriculum. The $2^{\text {nd }}$ teacher stated that she used 2013 curriculum only once. In the interview session she stated that

$2^{\text {nd }}$ Teacher $\quad$ : Okay. I will share it to you Mr. Indra. And then, firstly, I used school based curriculum in teaching ESP but...I have ever taught 2013 curriculum for about...six months but it is only in one semester.

Interviewer : Okay. Only one semester ya?

$2^{\text {nd }}$ Teacher $\quad$ : Yes...just one semester. And after that, it is changed again to the school based curriculum or KTSP.

In addition, she stated that it is really difficult to teach English by using 2013 curriculum, because she only has two hours a week to teach the students. Then there are too many genre texts in the material. However, the $2^{\text {nd }}$ teacher feels that it is better to teach practical English for her students, than the genre based text.

Then, according to the questionnaire, there are two major challenges faced by the $3^{\text {rd }}$ teacher. The first is her difficulties in making lesson plan. Lesson plan is one of important things for the success of teaching and learning process. Without a good preparation which is written in the lesson plan, it is hard for the teacher to create an attractive teaching and learning class. In the questionnaire, she stated that

Yes, I found some challenges. The challenges was from me as a teacher, because I felt it is still difficult to understand or to make a good lesson plan, so it will give effect in teaching material/ teaching process. And the second from the school itself. 
Therefore, it can be concluded if the $3^{\text {rd }}$ teacher knows her weaknesses in creating a good lesson plan, she knows the importance of lesson plan for her teaching. Hence, she tries to understand more about the lesson plan. The statement is in line with Jensen (2001) who stated that "a lesson plan is an extremely useful tool that serves as a combination guide, resources, and historical document reflecting our teaching philosophy, student population, textbooks, and most importantly, our goals for our students. It can also be used as a map that guides us in knowing what we want to do next".

The second problem is the support from the school. This problem is really common in developing countries such as Indonesia. The school and even government have weaknesses in developing the teachers' competences. For example, most of workshops or seminars organized by government are held only in the beginning when they release the new curriculum. But after that, the teachers are given total "freedom" to elaborate their understanding with the need in the field. Indonesian's teachers have become accustomed with that situation. However, it can be one of the biggest challenges for the teachers in the school.

Additionally, as a new teacher, the $4^{\text {th }}$ teacher finds some challenges. He thinks that his knowledge and information in teaching ESP is still low, for example towards the information in IT and automotive field. In the questionnaire he stated that

Yes I face some challenges. When I try to develop my professional competence. Honestly I don't know well about the name or the thing in IT and automotive. However I must learn it well to make the students understand what is actually I explaining about. Lack of seminar and workshop which concern with professional competence in teaching ESP makes me find out the point of my understanding autodidact.

The different material in Vocational school and general school is one of the challenges for the teacher because not all of the teachers in Indonesia are prepared to become an ESP teacher. The specific information in specific field sometimes makes the teacher little bit hesitant in teaching. The new teacher in ESP sometimes cannot separate whether he should teach English language in specific field or teach specific information in using English language.

Actually after a year teaching in that school, the $4^{\text {th }}$ teacher is known never joinseminars or workshops. Actually seminars and workshops can be one of the ways of new teacher to enhance his knowledge. The statement is supported by Richards and Farrell (2005) who stated that workshop take teachers out of the classroom to a forum where they can share challenges and concern with colleagues or teachers from different school. They also can serve to rekindle teachers' enthusiasm for teaching. The concentrated nature of a workshop also helps to maintain participants' interest level. However according to statement above, it can be concluded that the $4^{\text {th }}$ teacher has 
been aware about the importance of seminar or workshop on his career, even though until right now, he never joins those seminars and workshops.

Moreover, The $5^{\text {th }}$ teacher explainssomechallenges in developing her professional competence. She thinks that the seminar is rarely held in her city. The seminar which is organized by the government can also be counted by her fingers. In the interview session, she stated that

And then because sometime it is little bit.. not sometime but it is often difficult for me to follow the seminar outside of the place that I live because you know the government... mmm... ask the teacher to teach twenty four hours and it means in a week we must teach six day and it is difficult for us to go out of the town and then if in a month we have free absent in teaching, therefore, the certification's fund we cannot get it so there are many,, there are many obstacle that we have to develop in my opinion something like that ... yeah.. and the following the seminar if it is available in our town I guess this is the effort that I can do.

Other problem is her availability in joining seminars. As a teacher who got certification, it is difficult for her in letting the class because she has responsibility to teach twenty four hours. When she cannot come to the class, she will get the penalty from the government that is lost her certification's fund. Therefore, it is dilemma for many teachers. As a certification teacher, she needs to develop her knowledge and information because that program is created to make the teacher more responsible in teaching, more knowledgeable in delivering the material, and other positive goals written by the government. In fact, the program is enchaining the teacher to develop her knowledge. When the teachers have to teach twenty four hours, it means that they have to teach six days in a week. These conditions make the $5^{\text {th }}$ teacher difficult to develop her knowledge through seminars or workshops.

The Table 1 shows the challenges faced by the vocational teachers in developing their professional competence.

Table 1. Teachers' Challenges in Developing their Professional Competence

\begin{tabular}{cl}
\hline Teacher & \multicolumn{1}{c}{ Challenges } \\
\hline $\mathbf{1}^{\text {st }}$ & 1. Lack of understanding in the implementation of 2013 Curriculum. \\
& 2. Limited access of the internet. \\
& 3. Limited access to join seminar or workshop in her city. \\
\hline $\mathbf{2}^{\text {nd }}$ & 1. The challenges to join the seminar or workshop. \\
& 2. Lack of facilities and infrastructures to support her development. \\
\hline
\end{tabular}


3. The difficulties in understanding the new curriculum.

$3^{\text {rd }}$ 1. The difficulties in making and developing the lesson plan.

2. Minimum support from the school to develop her competencies.

$4^{\text {th }} \quad$ 1. As a new teacher in his school, he thinks that he has limited knowledge and information towards ESP teaching.

2. Difficulties in finding seminar or workshop in his city to develop his knowledge.

$5^{\text {th }} \quad$ 1. She rarely joins the seminar and workshop.

2. The availability of her in joining the seminar or workshop outside the city.

\section{Conclusions}

Most of the challenge of ESP teachers in developing their professional competence isthe availability of seminars or workshops in their city. Actually, most of the teachers understand and have the will to join seminars or workshops to develop their knowledge. However, not all of the teachers get those opportunities. This statement is in line with Richards and Farrell (2005) who explained seminar as a session or series of sessions in which group of experienced people discuss an issue and exchange information and experience. The second challenge which is usually faced by the teachers is the support from the schools or institutions. Most of the teachers explained that there is no program created by the schools to send their teachers to join the seminar or workshop. Therefore, when the teachers want to join the seminar or workshop, they have to find and pay by themselves. The last challenge is about the facilities and infrastructure in the school. The teachers stated that to improve their knowledge and information, sometimes they need to bring or provide it by themselves. For example, when they need internet access in the school but the internet network is down. Hence, they need to provide it by themselves. 


\section{References}

Bedi, K., \& Sharma, J. K. (2006). Benchmarking the quality of secondary education at the micro and policy imperatives.U21 Global working paper number 13/ 2006.Downloaded from www.u21global.ed.sg.

Benson, J. (2005). 'A complete education?' Observation about the state of primary education in Tanzania. Hakielimu, working paper, 1, 2006.

Crick, R. D. (2008). Key competencies for education in a European context: narratives of accountability or care. European Educational Research Journal Vol 7 No 3.

Davidson, E. (2006). The pivotal role of teacher motivation in Tanzania. Dar es salam: Hakielimu. Working paper journal 7.

Hanushek, E. A., \& Rivkin, S. G. (2006). Teacher Quality. In E. A. Hanushek and F. Welsh (EDS.), Handbook of the Economics of Education (Vol. 2, pp). 10511078. Amsterdam, Netherlands: Elsevier.

Hutchinson, T., \& Waters, A. (1987). English for Specific Purposes; A learningcentered approach. New York: Cambridge University Press.

Jamal, M. (2009). Seven teacher competence fun and professional. Jogjakarta: Powerbooks.

Jensen, L. (2001). Lesson Planning. in Teaching English as second and foreign language. $\mathrm{n}$ M. Celce-Murcia (Ed.) Teaching English as a second or foreign language. Boston: Heinle \& Heinle.

Johns, A. M., \& Price-Machado, D. (2001). English for Specific Purposes (ESP): Tailoring courses to students' needs-and to the outside world. In M. CelceMurcia (Ed.) Teaching English as a second or foreign language (pp. 43-54). Boston: Heinle \& Heinle.

Joyce, B., \& Showers, B. (2002). Student achievement through staff development. Alexandria. Virginia: Association for Supervision and Curriculum Development.

Krauss, S., Brunner, M., Kunter, M., Neubrand, M., Baumert, J \& Blum, W. (2008). Pedagogical content knowledge and content knowledge of secondary mathematics teachers. Journal of Educational Psychology, Washington, DC: American Psychological Association.

Malekela, G. (2000). Quality of Secondary school education in Tanzania. In J.C.J. Galabawa, F.M.K. Senkoro and A.F. Lwaitama (eds) The quality of Education 
in Tanzania: Issues and experiences. Faculty of Education, University of Dar es Salaam.

Marzano, R., Pickering, D., \& Pollock, J. (2001). Classroom instruction that works. Alexandria, Virginia: Association for Supervision and Curriculum Development.

Richard, J. C., \& Farrel, T. S. C. (2005). Professional Development for Language Teachers. New York: Cambridge University Press.

Robinson, P. C. (1991). ESP Today: A Practitioner's Guide. New York: Prentice Hall International.

Schon, D. A. (1983). Educating the reflective practitioner. San Francisco: JosseyBass Press.

Shahzad, S. (2007). A study to investigate the quality of education at intermediate level in Punjab. Doctoral thesis, university of Arid Agriculture, Rawalpindi, Pakistan.

Wedgwood, R. (2006). Education and poverty reduction in Tanzania. Working paper series 9. Hakielimu: Dar es salaam. 